\title{
THE OCCURRENCE AND GEODYNAMIC SIGNIFICANCE OF THE VOLCANO- SEDIMENTARY TYROS-BEDS (BASE OF THE GAVROVO-TRIPOLIS UNIT) ON RHODES ISLAND, DODEKANESE, SE AEGEAN
}

\author{
E. LEKKAS ${ }^{1}$, G. DANAMOS ${ }^{1}$, E. SKOURTSOS ${ }^{1}$, D. SAKELLARIOU ${ }^{2}$
}

\begin{abstract}
The Archangelos volcano-sedimentary formation is described here. It outcrops at the base of the alpine Archangelos unit of Rhodes island and displays sedimentary and lithological characteristics, which allow its correlation with the Upper Paleozoic - Upper Triassic Tyros-beds, known from the base Gavrovo-Tripolis unit in Peloponnesus, Kythira and Crete. Consequently Archangelos unit is correlated with the Gavrovo-Tripolis unit. Moreover it is suggested that Tyros-beds characterize the base of the external carbonate platform of Hellenides all along the southern Hellenic Arc, from Peloponnesus through Kythira and Crete to Rhodes Island.
\end{abstract}

KEY WORDS: Tyros-beds, volcano-sedimentary, Rhodes, geodynamic evolution

\section{INTRODUCTION - GEOTECTONIC UNITS OF RHODES ISLAND}

The alpine geotectonic structure of Rhodes island is quite complicate as can be concluded by many different opinions and hypotheses that have been expressed by the numerous geologists since the beginning of this century. Thus, basic characteristics of the alpine structure of Rhodes, as the number and the nature of the alpine units, the time span covered by their litho-stratigraphic columns, the tectonic relation between them as well as their correlation with equivalent units occurring in mainland Greece, still remain obscure. To summarize the various aspects and hypotheses expressed in the existing literature, six at least distinct alpine geotectonic units have been recognized.

Most of the workers agree that the metamorphic Lindos unit is the structurally lowermost and paleogeographically most external unit on the island (Aubouin \& Dercourt 1970, Mutti et al. 1970) and corresponds either to the Ionian or to the metamorphic Mani ("Plattenkalk") unit (Pozzi \& Orombelli 1965, Leboulenger \& Matesco 1975, Papanikolaou et al. 1995). The Lindos unit is tectonically overlain by a wild flysch formation, called by Papanikolaou et al. (1995) and Lekkas et al. (2000) as Laerma Wild Flysch, which has served itself as the basal sliding "plane" of the movement of the entire nappe stack of the island.

The Attavyros-Akramitis unit is the lower allochthonous unit above the Laerma Wild Flysch. The succession of the litho- and biofacies of the Attavyros-Akramitis unit lithostratigraphy is identical to the one of the Ionian unit of mainland Greece and Crete. Therefore it has been considered as the equivalent of the Ionian unit in the SE extremity of the Hellenic orogenic belt (Renz 1929, 1955, Orombelli \& Pozzi 1967, Aubouin \& Dercourt 1970, Mutti et al. 1970, Leboulenger \& Matesco 1975, Papanikolaou et al. 1995, Lekkas et al. 2000) although Harbury \& Hall (1988) proposed a paleogeographic position for the unit between the Pindos basin and the Gavrovo - Tripolis shallow platform.

Archangelos unit is composed of a thick sequence of massive to thick bedded limestones and dolomites of Upper Triassic to Lower Eocene and a Lower Eocene flysch on top of them (Mutti et al. 1970, Leboulenger \& Matesco 1975). All authors agree on the allochthony of the unit, which rests on the Laerma Wild Flysch (Papanikolaou et al. 1995). Renz $(1929,1955)$ and Mutti et al. (1970) compare it with Parnassos - Giona unit of mainland Greece while Orombelli \& Pozzi (1967) suggest a paleogeographic position close to the Gavrovo zone. Aubouin \& Dercourt (1970), Leboulenger \& Matesco (1975) and Papanikolaou et al. (1995) ascribed the calcareous sequence of the unit to Gavrovo - Tripolis platform on the basis of the Eocene age of the uppermost carbonate horizons as well as its tectonic position below the Profitis Ilias unit.

The latter Profitis Ilias unit is composed of pelagic limestones, red marls and radiolarites of Upper Triassic to Upper Cretaceous age and undoubtfully corresponds to the Pindos unit by all authors listed previously. The

1. University of Athens, Dept. of Geology, Panepistimioupoli, 15784 Athens

2. NCMR, Fleming 14, 16672 Vari Greece 


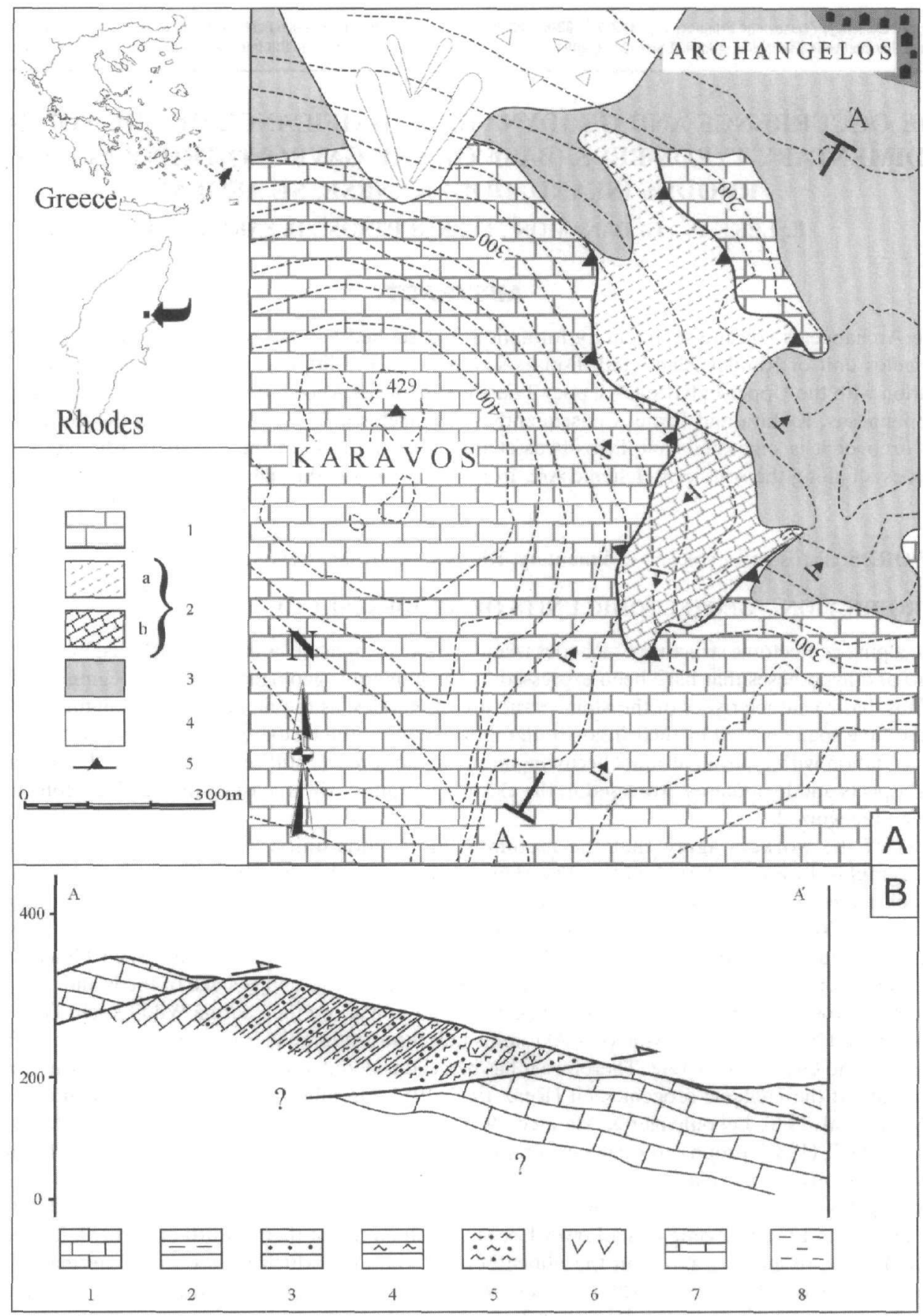

Fig. 1 A. Geological map of the area SW of Archangelos. 1. Archangelos unit neritic limestones, 2(a). Volcanoclastic sediments of "Tyros-beds" (formation 1 of the description of the profile), 2(b). Transitional beds from the volcanoclastic "Tyros-beds" to the platform carbonate sediments (formations 2-8 of the description of the profile), 3. Coastal deposits (Pleistocene), 4. Scree, 5. Tectonic contact.

B. Geological cross section A-A'. 1. Neritic limestones, 2. Pelites, 3. Sandstones, 4. Tuffites, 5. "Tyros-beds" volcanoclastic sediments, 6. Andesite and diabase bodies in the volcanoclastic sediments of "Tyros-beds", 7. Brecciated limestones of the transitional beds, 8. Coastal deposits (Pleistocene). 
uppermost nappe of Rhodes island is composed of ophiolitic rocks (gabbros, diabases and serpentinites) which lay tectonically on top of the Profitis Ilias unit (Aubouin \& Dercourt 1970, Leboulenger \& Matesco 1975, Papanikolaou et al. 1995). On the contrary MUTTI et al. (1970) believe that the ophiolites are tectonically emplaced between the Archangelos unit below and the Profitis Ilias unit above. Aubouin \& Dercourt (1970) ascribed the ophiolitic remnants of Rhodes to the "Subpelagonian Zone" while Papanikolaou et al. (1995) to the Pindos oceanic basin.

New data concerning the nature of the base of Archangelos unit lithostratigraphic column were collected recently from the area south of the homonymous village and may significantly improve our knowledge on the correlation of the various units of the island with the ones of mainland Greece and Crete.

\section{THE "TYROS-BEDS" OF RHODES: GEOGRAPHIC AND TECTONIC POSITION}

As mentioned above, the dominant hypothesis in the existing literature favors the correlation of the Archangelos unit with the Gavrovo - Tripolis unit of mainland Greece. The correlation between these two stratigraphically and tectonically similar units is strongly supported by the occurrence of a volcano-sedimentary sequence at the base of the platform of Archangelos unit, which is very similar to the Tyros-beds.

The Upper Paleozoic - Upper Triassic volcano-sedimentary formation at the base of the Gavrovo-Tripolis shallow platform has been recognized very early (Ktenas 1926) and repeatedly described since then (Brauer et al. 1980, Skarpelis 1982, Brauer 1983, Gerolymatos 1994, Dornsiepen \& Manutsoglu 1996, and many others). The continuous transition from the volcano-clastic sediments of "Tyros-beds" to the Gavrovo-Tripolis platform has been already described at various places in Peloponnesus (Tataris \& Maragoudakis 1967, Fytrolakis 1971, Lekkas \& Papanikolaou 1978, Thiebault 1982) and Crete (Bonneau \& Karakitsios 1979, Fytrolakis 1980). Danamos $(1991,1992)$ reports a tectonic relation between the underlying Tyros-beds and the overlying shallow water carbonates.

The occurrence of the volcano - sedimentary sequence, southwest of the Archangelos village, has been already found by Migliorini \& Venzo (1934) and Mutti et al. (1970) but its paleogeographic position has remained obscure.

The stratigraphically lower horizons of the Archangelos unit, which contain the volcano-sedimentary formation, outcrop on the eastern slope of Mt. Karavos, 500-600m southwest of the Archangelos village, at the central eastern part of Rhodes island (Fig. 1). They are tectonically emplaced in-between calcareous sediments of the Archangelos neritic plateau and are partly covered transgressionally by Quaternary shore deposits (Fig. 2). The profile presented below has been described and studied along the road climbing the eastern slope of Mt. Karavos.

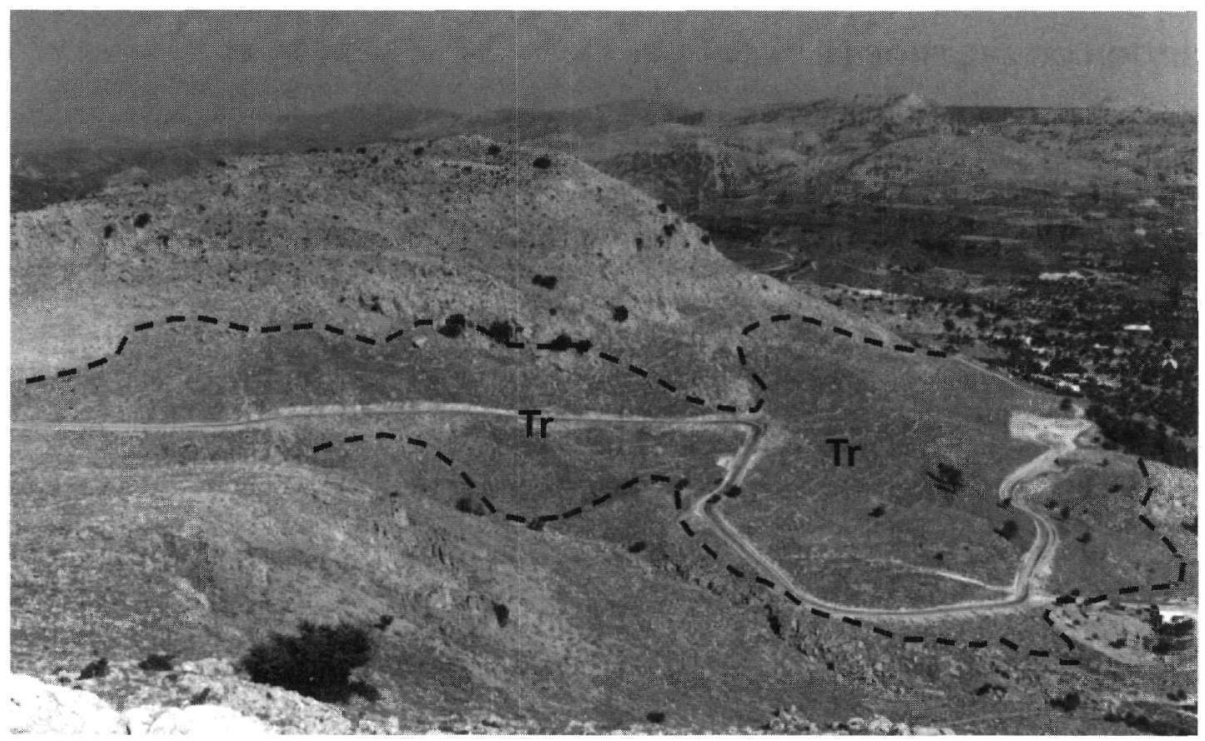

Fig. 2 Tyros-beds (Tr) outcrop in the Archangelos area. View from the east. 


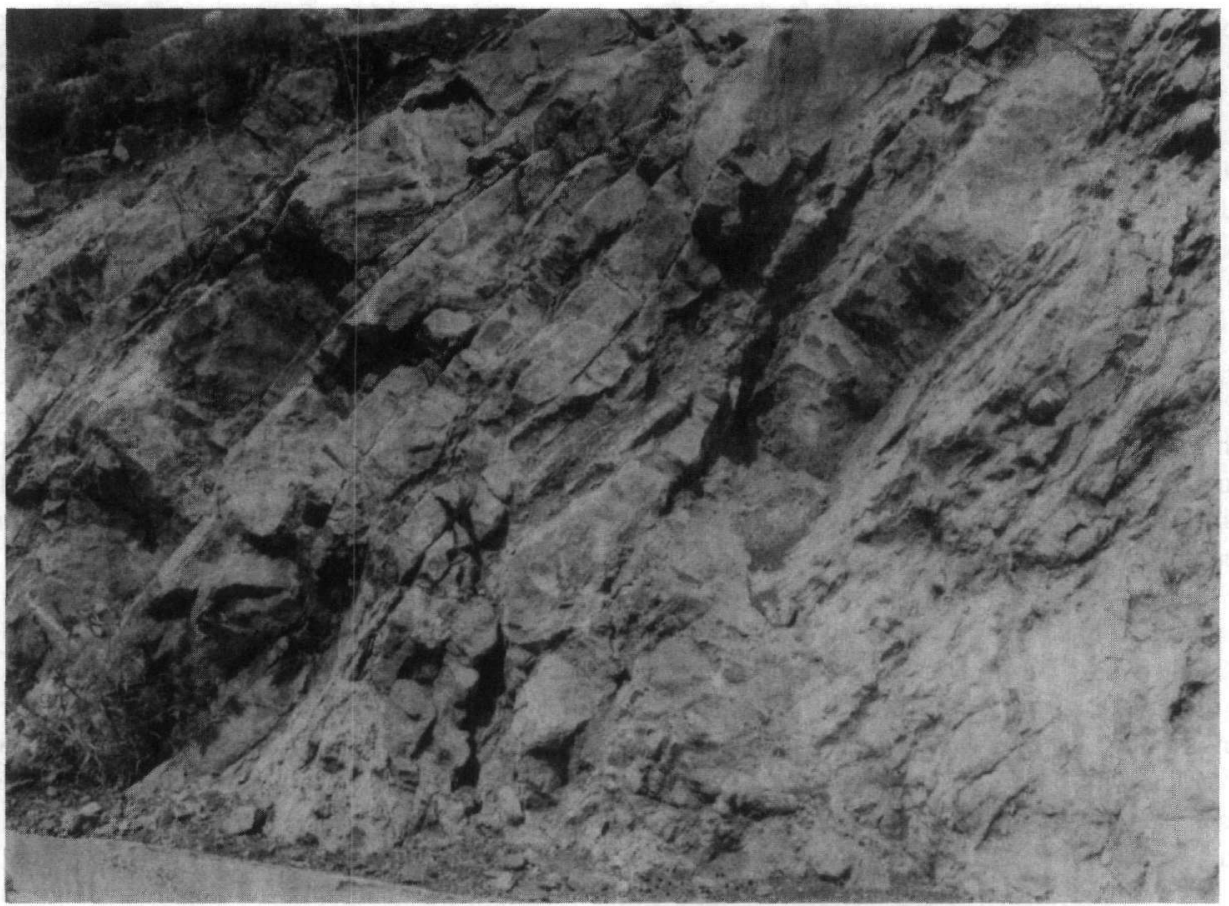

Fig. 3 Transitional beds between the volcanoclastic series and the carbonate sediments of the platform.

The strata of the sequence strike NW-SE and SW-wards with $40^{\circ}-70^{\circ}$ (Fig. 3). They lay tectonically on white to pinkish, thick bedded or massive, micritic to microbrechique and dolomitic limestones of Archagellos unit. The age of the calcareous sediments remains unknown, since no fossils were found but at the base of their sedimentary character we ascribe them to Upper Triassic - Lower Middle Jurassic. The volcano-sedimentary formation itself is overlaid tectonically by white to pinkish $1-1,5 \mathrm{~m}$ thick bedded microbrechique or endomicritic limestones, which contain angular and rounded limestone clasts and dip NE-wards. (Fig. 4).

\section{DESCRIPTION OF THE PROFILE}

The volcano-sedimentary formation near Archangelos village prevails the following litho-stratigraphy from the stratigraphical lower to the higher levels.

- The stratigraphically lower horizons are composed of alternations of pelites and tuffs with rare intercalations of sandstone and limestone horizons. Green and rosa layers or rounded bodies of igneous rocks, as well as foliated and strongly alterated pillow lavas, are usually observed within the clastic sediments. Quartz, plagioclast, green amphibole, chlorite and opaque minerals have been observed in thin sections from the volcanoclastic, tuff layers. Mineralogical analysis on thin sections from the lava layers and rounded bodies revealed andesitic to diabasic composition with diopside phenocrystals flowing within microlithic matrix composed of plagioclast, chlorite, epidote, calcite and opaque minerals. The sandstone and limestone horizons become more abundant towards the higher stratigraphical levels. The calcareous layers are endobiomicritic to bioclastic limestones and contain fragments of algae, echinoderms and corals. Their thickness does not exceed $40 \mathrm{~cm}$. The total thickness of this part of the sequence reaches $250-300 \mathrm{~m}$ (Fig. 5).

- Upwards follows a 4-5m thick sequence of yellowish sandstones and pelites within which greenish tuffs and gray, brechique to microbrechique limestone beds of $10-12 \mathrm{~cm}$ thickness are intercalated. The limestones become thicker (up to $40-50 \mathrm{~cm}$ ) upwards and contain fragments of algae and echinus needles. Large calcareous clasts of up to $1,5 \mathrm{~m}$ in diameter have been deposited within the clastic sediments.

- Alternations of thin green-gray pelites and yellow-grayish limestones of $15 \mathrm{~m}$ total thickness follow. The thickness of the limestone horizons increases towards the top of the sequence from $1-15 \mathrm{~cm}$ to $10-30 \mathrm{~cm}$. They are microbrechique and contain fragments of corals and bryozoa, unilinear foraminifera, algae and crinoides (Encrinus liliiformis) of Middle Triassic age. At the top of the sequence, a $30 \mathrm{~cm}$ thick microbrechique to 
bioclastic limestone horizon contains coral fragments, bryozoa, crinoides (Encrinus liliiformis), algae (Diplopora $s p$.), foraminifera and Echinus needles of Middle Triassic (Fig. 6).

- Thickness $30-32 \mathrm{~m}$. Limestones and pelites with rare intercalations of 20-40 cm thick green tuffs and $12-15 \mathrm{~cm}$ thick yellow sandstones. Two facies of limestone horizons have been observed within this sequence. The first one corresponds to gray micritic limestones of 1-6cm thickness, which contain Echinus needles. The second facies corresponds to brechiques bioclastic limestone horizons of $10-40 \mathrm{~cm}$ thickness with some algae fragments and recrystallized coral fragments.

- Thickness $5 \mathrm{~m}$. Limestones with rare intercalations of green and yellow pelites. The thickness of the calcareous beds reaches $60 \mathrm{~cm}$.

- $1 \mathrm{~m}$ thick green pelites and tuffs.

- Thickness $45 \mathrm{~m}$. Alternations of up to $1 \mathrm{~m}$ thick limestone beds with up to $30-35 \mathrm{~cm}$ thick pelites and yellow to green tuffaceous horizons with rare intercalations of sandstones. The brechique limestone layers contain big fragments of crinoides (Encrinus liliiformis), recrystallized algae fragments, (Diplopora sp.), rounded and angular micritic pebbles and bryozoa. Their age is Middle Triassic.

- Thickness $10 \mathrm{~m}$. Alternations of $5-25 \mathrm{~cm}$ thick limestone beds and $5-10 \mathrm{~cm}$ thick pelitic horizons. The micritic facies become more rare.

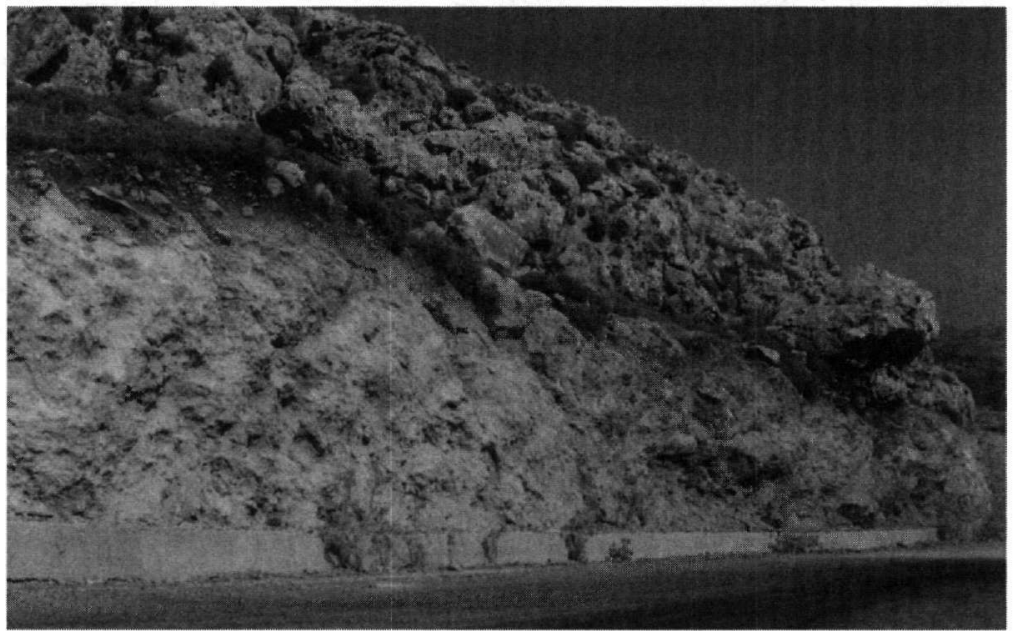

Fig. 4 Tectonic displacement of the carbonate sediments over the volcanoclastic Tyros-beds.

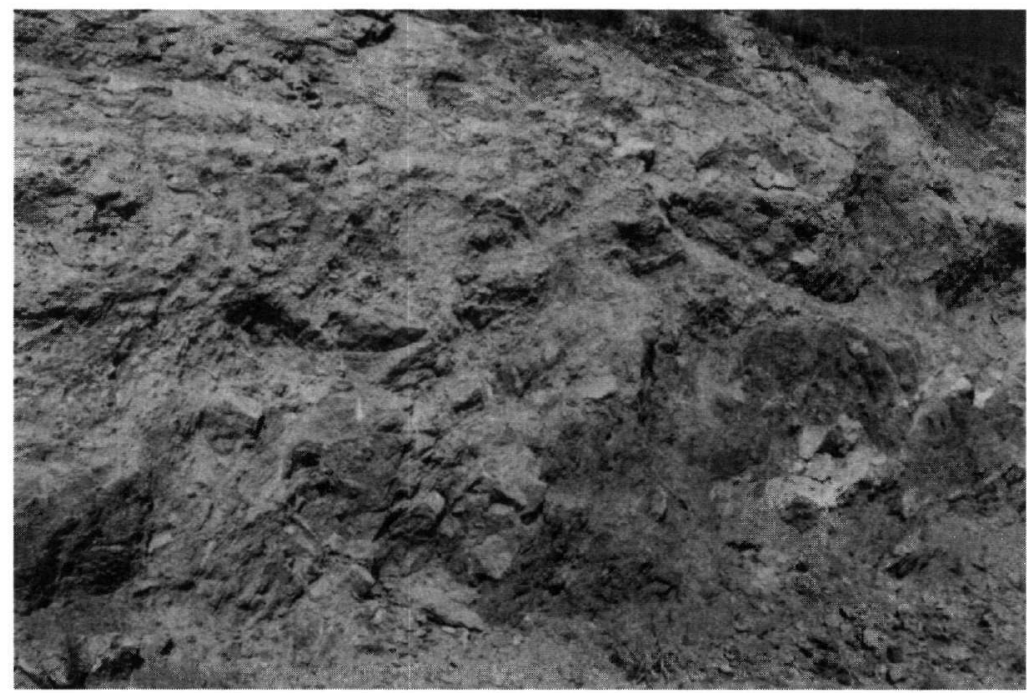

Fig. 5 Andesite and diabase bodies in the pelites and tuffs of the volcanoclastic series. 


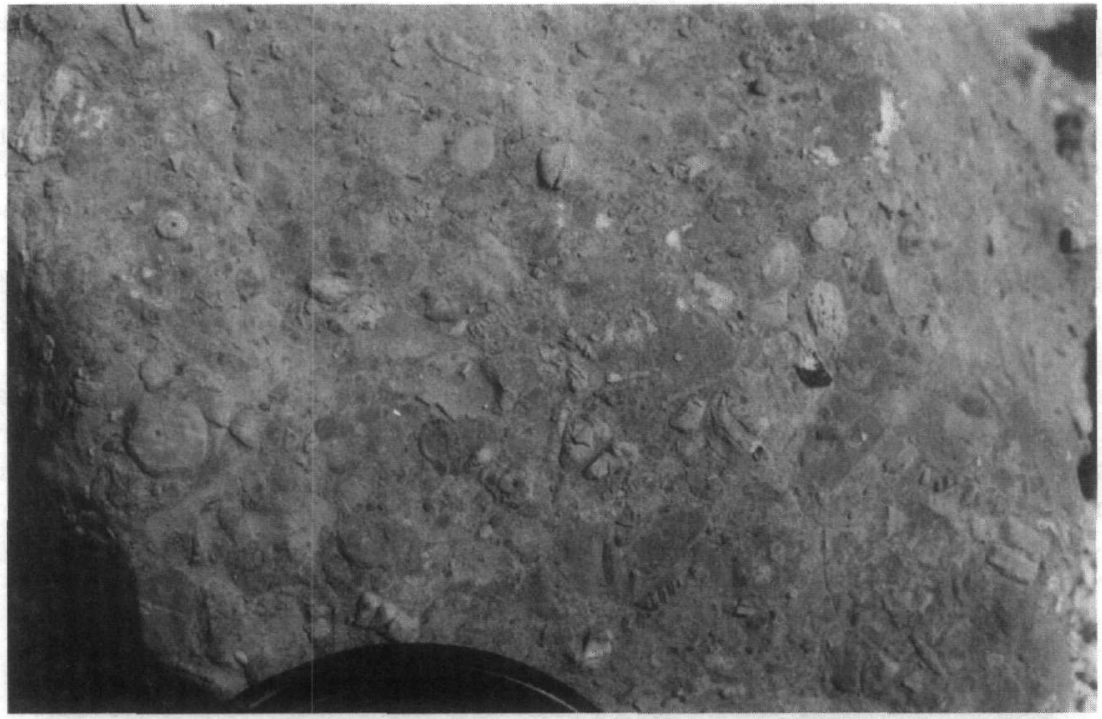

Fig. 6 Brecciated, bioclastic limestones with sections of Encrinus liliiformis (Middle Triassic).

\section{CONCLUSIONS - DISCUSSION}

The proposed equivalence of Archangelos volcano-sedimentary formation of Rhodes island to the Upper Paleozoic - Upper Triassic Tyros-beds, which are known from many places of Peloponnesus, Kythira island and Crete, provides significant new aspects for the geological structure of Rhodes island. The presence of the Tyroslike formation at the base of Archangelos unit, the Eocene age of the uppermost carbonate horizons of the unit below the flysch and the structural position of the unit below the Profitis Ilias (Pindos) nappe, support strongly the correlation between Archangelos and Gavrovo - Tripolis units.

Moreover the equivalence between Archangelos volcano-sedimentary formation and Tyros-beds indicates that the latter constitutes a basic characteristic of the entire palaeogeographic area of the external carbonate platform of Hellenides, from Peloponnesus through Kythira and Crete to Rhodes, before the onset of the neritic sedimentation in Middle - Upper Triassic.

The deposition of clastic sediments, accompanied by andesitic volcanism with lava flows and tuff layers, predates the onset of the shallow marine calcareous sedimentation of the Gavrovo-Tripolis unit and is present throughout the entire paleogeographic area of the unit. It is noteworthy that the sedimentary facies and the lithological characteristics of the Upper Paleozoic - Upper Triassic volcano-sedimentary Tyros-beds formation remain more or less constant all along the southern Hellenic Arc.

The origin of the volcanic rocks that accompany the clastic sediments is enigmatic. Until now two aspects have been proposed: The first aspect correlates these volcanic rocks with a subduction zone (Panagos et al. 1979, Pe-Piper \& Kotopouli 1981, Skarpelis 1982, Gerolymatos 1994, Dornsiepen \& Manutsoglu 1996). The second one correlates them with a drifting of a continental terrain away from the former Gondwana continent (Thiebault 1982, Thiebault et al. 1985).

\section{REFERENCES}

AUBOUIN, J. \& DERCOURT, J. 1970. Sur la geologie de l' Egee: regard sur le Dode-canese meridional (Kassos, Karpathos, Rhodes). Bull. Soc. Geol. Fr., (7), XII, p. 455-472.

BONNEAU, M. \& KARAKITSIOS V. 1979. Les niveaux inferieurs (Trias superieur) de la nappe de Tripolitza en Crete moyen (Grece) et leurs relations avec la nappe des Phyllades. Problemes stratigraphiques, tectoniques et de metamorphisme. C.R.Acad. Sc. Paris, (D), 288, 15-16.

BRAUER, R. 1983. Das Praneogen im Raum Molaoi-Talanta/SE-Lakonien (Peloponnes, Griechenland), Frankfurter geowiss. Ard., Serie A, Bd., 284S., Frankurt.

BRAUER, R., ITTNER, R. \& KOWAZCZYK, G. 1980. Ergebnisse aus der "Phyllite-Serie" SE-Lakoniens, N. Jb. Geol. Palaont. Mh., 3, 129-144, Stuttgart. 
DANAMOS, G. 1991. Presence of volcanosedimentary series of "Tyros beds" on Kythira island. Bull. Geol. Soc. Greece, 25/1, 399-404.

DANAMOS, G. 1992. Contribution to the geology and hydrogeology of the Kythira island, Greece. Thesis, 335p., Athens.

DORNSIEPEN, U. \& MANUTSOGLU, E. 1996. Die Vulkanite der Tyros-Schichten Kretas und des Peloponnesorogene Andesite ider anorogene Trapp-Basalte?, Z. dt. Geol. Ges., 147/1, s. 101-123, Stuttgart.

FYTROLAKIS, N. 1971. The Palaeozoic beds SE of Kalamata region. Bull. Geol. Soc. Greece, 8/1, 70-81.

FYTROLAKIS, N. 1980. The geological structure of the Crete island. Athens 1980, 146p.

GEROLYMATOS, I. 1994. Metamorphose und tektonik der Phyllit_Quartzite-Serie und der Tyros-Schichten auf dem Peloponnes und Kythira. Berliner geowiss. Abh. (A), 164, 101 s., Berlin.

HARBURY, N. \& HALL, R. 1988. Mesozoic extensional history of the southern Tethyan continental margin in the SE Aegean. J. Geol. Soc., London, 145, 283-301.

KTENAS, K.A. 1926. Formations primaires semimetamorphique au Peloponnesus central. C. R. Somm. Soc. Geol. France, 24, 61-63, Paris.

LEBOUlENGER, P. \& MATESCO, S. 1975. Contribution a l' etude geologique de l' are egeen: 1' ile de Rhodes. Theses $3 e$ cycle, Universite P. et M. Curie, Paris.

LEKKAS, S. \& PAPANIKOLAOU, D. 1978. On the phyllite problem in Peloponnesus. Ann. Geol. Pays Hell., 29/1, 395-410.

LEKKAS, E., PAPANIKOLAOU, D. \& SAKELLARIOU D. 2000. Neotectonic map of Greece, 1:100.000 scale: Rhodes sheet. European Center on Prevention and Forecasting of Earthquakes, Earthquake Planning and Protection Organization.

MIGLIORINI, C. \& VENZO, S. 1934. Il Ladinico superiore dell' Isola di Rodi (Egeo). Palaeont. Ital., 34, p. 137-170, 1 pl., 2 figs, Siena.

MUTTI, E., OROMBELLI, G. \& POZZI, R. 1970. Geological Studies of the Dodecanese Islands (Aegean Sea). Geological map of the Island of Rhodes and Explanatory Notes. Ann. Geol. des Pays Helleniques, 22, p. 77-226.

OROMBELLI, G. \& POZZI, R. 1967. Studi geologici sulle isola del Dodecaneso (Mare Egeo). V-Il Mesozoico nell’ isola di Rodi (Grecia). Riv. Ital. Paleont. Strat., 73, 409-536.

PANAGOS, A., PE, G., PIPER,D., KOTOPOULI, C. 1979. Age and stratigraphic subdivision of the phyllite series, Krokee region, Peloponnese, Greece. N. Jb. Geol. Palaont. Mh., 3, 181-190, Stuttgart.

PAPANIKOLAOU, D., LEKKAS E. \& SAKELLARIOU D. 1995. Tectonic units and terrane analysis in Rhodes and adjacent Dodekanese islands, Greece. XV Congr. Carpatho-Balcan Geol. Assoc., Symp. Tectonostratigraphic Terranes in CB Region, Athens, September 17-20, 1995, Abstracts, p. 20

PE-PIPER, G. \& KOTOPOULI, C. 1981. Very low grade metamorphism of Triassic volvanics, West Hellenic nappes, southern Peloponnese, Greece. Summary, Bull. Soc. Geol. Am., Part I, 92, 914-916.

POZZI, R. \& OROMBELLI, G. 1965. Studi geologici sulle isole del Dodecaneso (Mare Egeo). Sull' eta cenomaniana dei Calcari di Lindo (Isola di Rodi, Grecia). Rend. Acc. Naz. Lincei, 8, 38, 897-901.

RENZ, C. 1929. Geologische Untersuchungen auf den Inseln Cypern und Rhodes. Prakt. Acad. Athenes, 4, p. 301-314, Athenes.

RENZ, C. 1955. Dia vorneogene Stratigraphie der normalsedimentaren Formationen Griechenlands. Inst. Geol. Subsurf. Res., 637p, Athen.

SKARPELIS, N. 1982. Metallogeny of massive sulfides and petrology of the external metamorphic belt of Hellenides (SE Peloponnesus). Diss. Univ. Athens, 149p., Athens.

TATARIS, A. \& MARAGOUDAKIS, N. 1967. On the stratigraphy of Triassic and Jurassic of the Tripolis zone at Kynouria (Peloponnes). Bull. Geol. Soc. Greece, 6/2, 353-364.

THIEBAULT, F. 1982. Evolution geodynamique des Hellenides externes en Peloponnese meridional (Grece). Soc. Geol. Nord, 6, 574p.

THIEBAULT, F., LALLEMANT, S., LYBERIS, N. \& ZANINETTI, L. 1985. Precisions stratigraphiques, structurales et metamorphiques sur les nappes des Phyllades et de Gavrovo-Tripolitza dans la region de Krokee (Peloponnese meridional, Grece). Consequences sur l' interpretation du volcanisme "andesitique" triasique. C. R. Acad. Sc. Paris, t. 300, Serie II, 13, 625-630. 